\title{
Promotion of cyst formation in the toxic dinoflagellate Alexandrium (Dinophyceae) by natural bacterial assemblages from Hiroshima Bay, Japan
}

\author{
Masao Adachi ${ }^{1, *}$, Tsukasa Kanno $^{1}$, Tomoyuki Matsubara ${ }^{1}$, Toshitaka Nishijima $^{1}$, \\ Shigeru Itakura ${ }^{2}$, Mineo Yamaguchi ${ }^{2}$ \\ ${ }^{1}$ Laboratory of Aquatic Environmental Science, Faculty of Agriculture, Kochi University, Kochi 783-8502, Japan \\ ${ }^{2}$ Harmful Algal Bloom Division, National Research Institute of Fisheries and Environment of Seto-Inland Sea, \\ Fisheries Agency of Japan, Ohno, Saeki, Hiroshima 739-0452, Japan
}

\begin{abstract}
The relationship between the abundance of the toxic marine dinoflagellate Alexandrium tamarense (Lebour) Balech and Alexandrium-cyst-formation-promoting bacteria (Alex-CFPB) was investigated in the water column of Hiroshima Bay (Japan) from 1997 to 1998. Cell density of A. tamarense increased gradually from February to the middle of April, then peaked at the end of April and blooms declined rapidly in the beginning of May in both years. All seawater fractions collected from $5 \mathrm{~m}$ depth, where the density of $A$. tamarense cells was highest and which also contained the bulk of planktonic bacteria, promoted cyst formation of A. catenella (Whedon and Kofoid) Balech. This promotion was not caused by effects from nutrient limitation. The number of Alex-CFPB in seawater samples, analyzed by means of the most probable number (MPN) method, increased from the beginning of the Alexandrium bloom and reached $3.60 \times 10^{3}$ and $1.00 \times 10^{3}$ cells ml-1 at the peak bloom period at the end of April in 1997 and 1998, respectively. As the blooms declined, the number of Alex-CFPB decreased rapidly to less than 10 cells $\mathrm{ml}^{-1}$. Alexandrium-cyst-formation-inhibiting bacteria (Alex-CFIB) were not detected. These results show a clear positive correlation between the abundance of $A$. tamarense and Alex-CFPB during blooms, which suggests that Alex-CFPB play a significant role in the process of encystment and bloom dynamics of Alexandrium in the field.
\end{abstract}

KEY WORDS: Alexandrium $\cdot$ Dinoflagellate $\cdot$ Bacteria $\cdot$ Cyst

\section{INTRODUCTION}

The toxic dinoflagellates Alexandrium catenella and A. tamarense commonly occur in temperate coastal waters throughout the world, resulting in recurrent outbreaks of Paralytic Shellfish Poisoning (PSP) (Hallegraeff 1993, Shumway 1993). Hiroshima Bay, a highly eutrophic, semi-enclosed embayment and a major shellfish culture area, is characterized by seasonal blooms of $A$. tamarense and shellfish toxicity is a recurrent annual problem.

The life cycles of these organisms are extremely important for their ability to form blooms. The domi-

\footnotetext{
•E-mail: madachi@cc.kochi-u.ac.jp
}

nant mode of reproduction is by simple asexual fission, but a transition to dioecious sexual reproduction can occur whereby motile mating types, plus and minus, which fuse to produce a motile diploid zygote (planozygote) are formed (Turpin et al. 1978, Yoshimatsu 1981). Planozygotes swim for several days before losing motility and becoming thick-walled resting cysts (hypnozygotes) (Pfiester \& Anderson 1987). When favorable growth conditions return, cysts germinate and reinoculate the water with vegetative swimming cells (Steidinger 1975, Dale 1977, Anderson \& Wall 1978). The roles suggested for these cysts include 'seed populations' for bloom initiation, short- and long-term survival through adverse conditions, species dispersal and preservation of genetic variation (Pfiester \& Anderson 1987). 
In laboratory cultures, sexuality in dinoflagellates has been reported to occur in response to stress following nitrogen and/or phosphorus depletion (Pfiester \& Anderson 1987). Environmental factors such as day length, temperature, light intensity, and dissolved gases have also been suggested as possible causes of sexuality (Pfiester \& Anderson 1987). Anderson et al. (1984) examined the total cyst yield of Alexandrium tamarense in response to variations in temperature, light and initial nutrient availability in batch cultures, with nitrogen (nitrate/nitrite and ammonium) and/or phosphorus depletion being found to enhance encystment. Life cycle stages and the sizes of intracellular and extracellular pools of limiting nutrients (phosphorus) during $A$. tamarense encystment in batch culture were also investigated, which clarified that sexuality was induced as cellular phosphorus decreased to a subsistence cell quota (Anderson \& Lindquist 1985). These laboratory culture experiments strongly suggest that sexuality of $A$. tamarense is induced by nutrient depletion.

There exist, however, field reports of encystment under seemingly favorable nutrient conditions for growth. Anderson \& Morel (1979), Anderson et al. (1983) and Perez et al. (1998) reported cyst formation for natural populations of Alexandrium tamarense in the presence of relatively high levels of nitrate and phosphate which were able to support vegetative growth. Despite the emphasis on nutrient depletion in experimental studies, the precise set of environmental cues that trigger/stimulate encystment in the field has not been clearly defined. Considering the importance of life cycle phenomena, the principal objective of this study was to examine the factors inducing/promoting sexuality and encystment in natural toxic Alexandrium populations.

Although several studies on factors controlling encystment of Alexandrium have considered physical (waier temperature and light intensity) (Anderson et al. 1984) and/or chemical aspects (inorganic nutrients or micro nutrients; e.g. iron) (Anderson et al. 1984, Anderson \& Lindquist 1985, Doucette et al. 1989), no information regarding biological factors has been reported to date. Recently, close relationships between microalgae and bacteria have been observed under laboratory conditions, which suggest that bacterial assemblages play significant roles in the succession of marine phytoplankton communities, especially in the development and disintegration of blooms (Riquelme et al. 1987, Fukami et al. 1991, Yoshinaga et al. 1995). In the present study, we have undertaken an investigation of bacterial effects on cyst formation in natural toxic Alexandrium populations in Hiroshima Bay (Japan) during 1997 to 1998. Relationships between the population dynamics of toxic Alexandrium and the abundance of the bacteria that affect encystment are also examined.

\section{MATERIALS AND METHODS}

Organisms and culture methods. All the experiments were conducted with clonal toxic isolate 6ax (tentatively mating type plus) and TNY7 (mating type minus) of Alexandrium catenella, which were originally established by R. Kondo in 1995 from Uchiumi, Naruto, Japan and by Y. Sako in 1987 from Tanabe Bay, Wakayama, Japan, respectively, We re-isolated these isolates axenically using the micropipette washing and dilution method described by Sako et al. (1990). Sterility of each culture was periodically determined by culture tests using a liquid peptone medium, as well as by direct bacteria observations with DAPI (4'6-diamidino-2-phenylindole) staining and epifluorescence microscopy as described by Imai \& Yamaguchi (1994). These cultures were grown in $\mathrm{f} / 2$ with no added silicate (f/2-Si) using $10^{-5} \mathrm{M} \mathrm{Fe-EDTA}$ as an iron source and chelator (Guillard \& Ryther 1962, Anderson et al. 1984). Media preparation included precautions to avoid precipitation or chemical contamination. All glassware was routinely washed with detergent and rinsed thoroughly, then soaked for several days in $2 \mathrm{~N} \mathrm{HCl}$ and rinsed again with deionized, distilled water. Cultures were grown at $20^{\circ} \mathrm{C}$ with a 14:10 h light:dark cycle at $80 \mu$ mol photons $\mathrm{m}^{-2} \mathrm{~s}^{-1}$, which was measured by Light Meter Model LI-250 (Li-Cor).

Field measurements and sampling. Sampling was conducted from January 1997 to June 1998 once a month during non-bloom periods or once a week during bloom periods, at Stn 11, a shallow coastal site in Hiroshima Bay, western Seto Inland Sea, Japan (Fig. 1). Water samples for Alexandrium tamarense cell. counts were taken with a Niskin sampling bottle (General Oceanics Inc.) from $0,2,5,10,20$, and $1 \mathrm{~m}$ above the bottom at Stn 11 (depth ca $22 \mathrm{~m}$ ). Water temperature and salinity were measured using a temperaturesalinity bridge (Model 602, Yeo-Kal), at the same depth and time water samples were collected. The number of vegetative cells of $A$. tamarense in $1 \mathrm{ml}$ of each sample concentrated from 500 to $10 \mathrm{ml}$ were counted under a light microscope on the day of sampling.

One liter of subsamples collected from the $5 \mathrm{~m}$ depth layer at Stn 11 was poured into acid-washed, autoclaved glass bottles and kept at $4{ }^{\circ} \mathrm{C}$ in the dark during transit to the laboratory for analysis of any bacterial effect on encystment. Nutrient samples were filtered through glass-fiber filters (GF/C) as well as $0.2 \mu \mathrm{m}$ cellulose acetate filters DISMIC-25cs (Advantec Inc.) and poured into $100 \mathrm{ml}$ acid-washed vials in the field and 


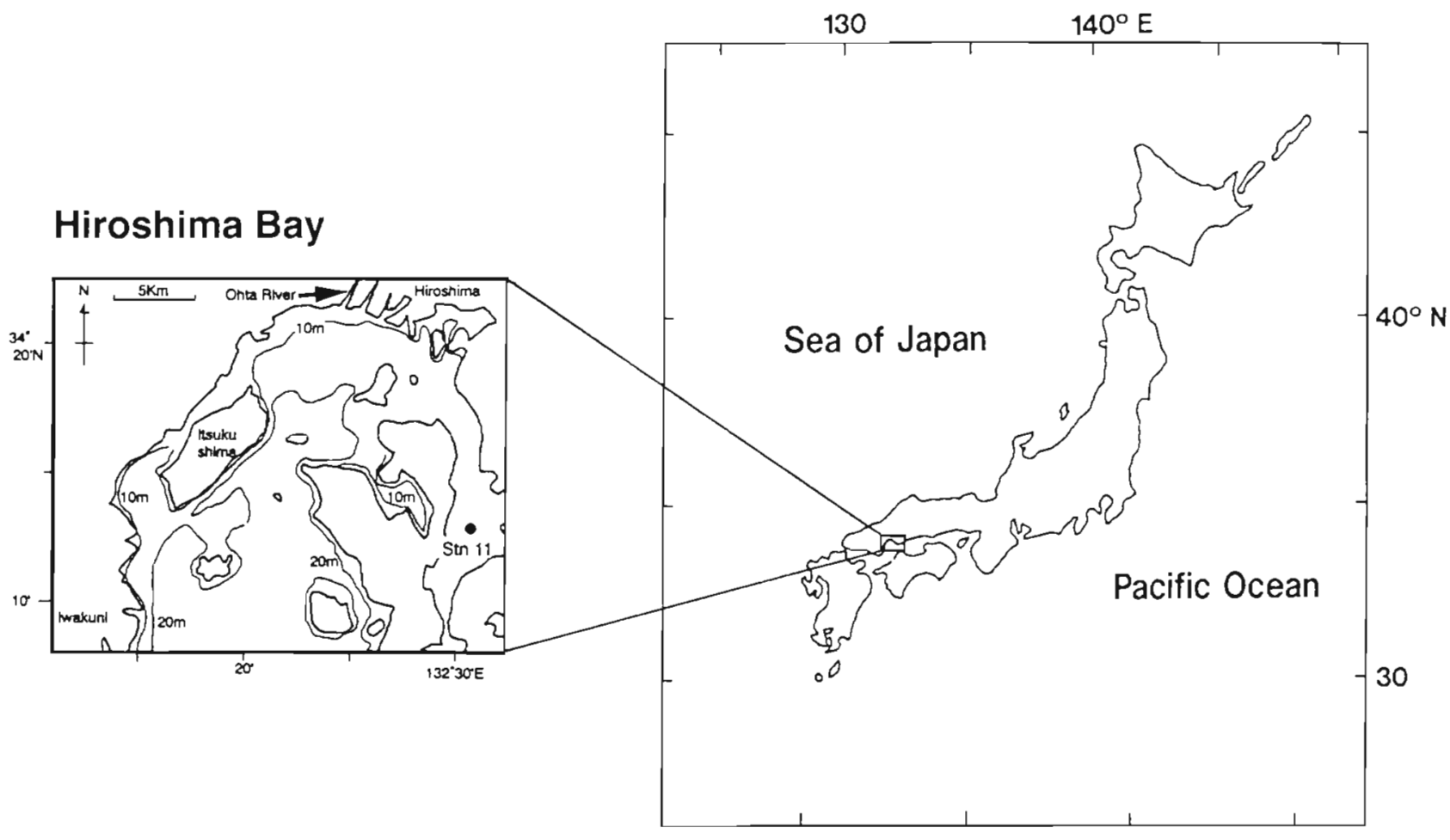

Fig. 1. Location of sampling station (Stn 11) in Hiroshima Bay, Japan

kept at $4^{\circ} \mathrm{C}$ until they could be frozen at $-20^{\circ} \mathrm{C}$. Reactive phosphate, nitrate/nitrite and ammonium concentration of collected seawater samples were determined by means of a TRAACS-800 ${ }^{\mathrm{TM}}$ autoanalyzer (Bran Luebbe) according to the recommendations of the manufacturer. One hundred $\mathrm{ml}$ subsamples for total bacterial counts were fixed in the field with neutralized formaldehyde (final conc. $2 \%$ ). The total bacterial number in seawater samples was determined by direct microscopic observations with DAPI staining (Porter \& Feig 1980).

Small-scale bioassay. Fig. 2 shows the procedure of the small-scale bioassay for the detection and tentative enumeration of bacteria in seawater samples collected from the $5 \mathrm{~m}$ depth layer at Stn 11 from 1997 to 1998 promoting or inhibiting cyst formation in Alexandrium. Since isolates of $A$. tamarense from Hiroshima Bay did not form cysts when they were mated with each other, we used strains of $A$. catenella for bioassays, which readily form more cysts, have a close phylogenetic relationship with A tamarense (Adachi et al. 1996), and form few cysts when mated with $A$ tamarense (Sako et al. 1990). Each seawater sample was first filtered through a glass-fiber filter $(\mathrm{GF} / \mathrm{F})$ and then through a $0.8 \mu \mathrm{m}$ Millipore or $0.2 \mu \mathrm{m}$ Nuclepore filter. The $0.8 \mu \mathrm{m}$ filtrate was considered as the fraction containing the bulk of the planktonic bacteria (BF) and the $0.2 \mu \mathrm{m}$ filtrate as the 'bacteria-free' fraction (BFF). The
$\mathrm{BF}$ filtrate was diluted serially from $10^{-1}$ to $10^{-5}$ with sterilized $\mathrm{BFF}$. BFF, $\mathrm{BF}$, serially diluted $\mathrm{BF}$ and $\mathrm{f} / 2-\mathrm{Si}$ medium $(0.5 \mathrm{ml})$ were each inoculated into 16 wells of 48-well disposable sterilized tissue culture microplates (Iwaki Co.), respectively. In parallel, cultures of 6ax and TNY7 in the mid-exponential growth phase were adjusted to a concentration of $5.0 \times 10^{3}$ cells $\mathrm{ml}^{-1}$ with sterile $\mathrm{f} / 2-\mathrm{Si}$ medium, respectively and mixed together. One $\mathrm{ml}$ of the mixed cell suspension was inoculated into each of the 48 microwells and was mixed gently and incubated at $20^{\circ} \mathrm{C}$ with a $14: 10 \mathrm{~h}$ light:dark cycle at $80 \mu \mathrm{mol}$ photons $\mathrm{m}^{-2} \mathrm{~s}^{-1}$. The inoculated microplates were tightly sealed with Parafilm to prevent evaporation. Two wk or 1 mo after the start of the incubation, the number of whole cysts formed in each well were counted under an inverted microscope IXFLA (Olympus). Cyst yields in these fractions from April 21, 1997, were statistically compared by 1-way ANOVA (Sokal \& Rohlf 1995). The wells in which the cyst number was more than 3 times and less than onethird of the mean cyst number formed in the bacteriafree wells ( $n=18$ ) were regarded tentatively as Alexandrium-cyst-formation-promoting and -cyst-formation-inhibiting bacteria (Alex-CFPB and AlexCFIB) positive, respectively. Most probable number (MPN) values of Alex-CFPB and Alex-CFIB in the seawater samples were calculated from the numbers of Alex-CFPB-and Alex-CFIB-positive wells using the 


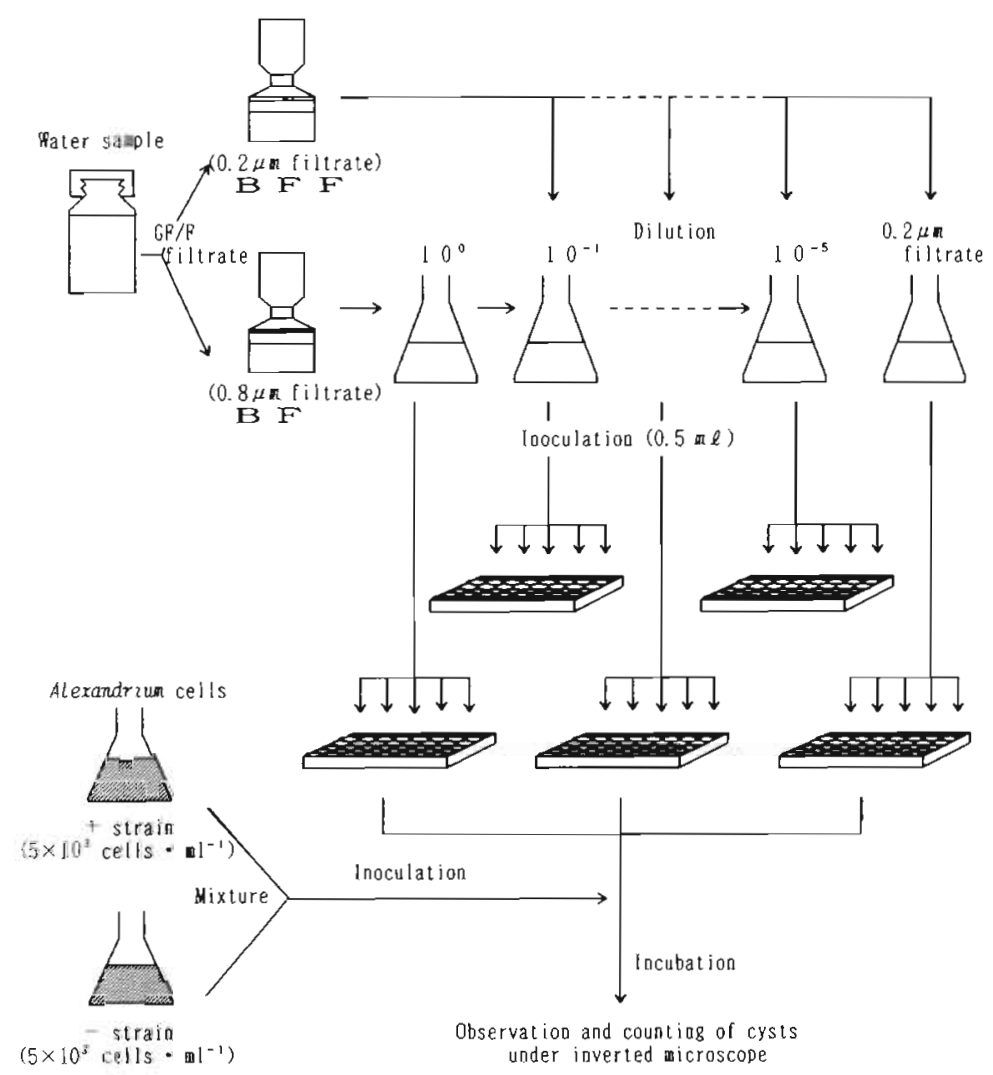

Fig. 2. Experimental procedure of the small-scale bioassay for detecting Alexandrium-cyst-formation-promoting and -cyst-formation-inhibiting bacteria

method of Imai et al. (1998). For the determination of excystment, cysts formed in the MPN wells were counted, stored at $5^{\circ} \mathrm{C}$ in the dark for $1 \mathrm{mo}$ and then incubated at $20^{\circ} \mathrm{C}$ for 1 mo according to the cyst maturation method described by Sako et al. (1992). After incubation, cysts were recounted. Excystment efficiency was obtained as the ratio of cyst number before cold treatment:the germinated cyst number 1 mo after the start of the incubation. At least 600 cysts formed in 3 wells (total 1800 cysts) were counted for excystment efficiency.

Large-scale bioassay. A multi-flask approach was used to obtain more detailed information on the time course of encystment using field samples taken from February 9 to May 21, 1998. Twenty ml of BF or BFF from each seawater sample was poured into 15 sterile flasks of $100 \mathrm{ml}$ for each fraction. Twenty $\mathrm{ml}$ of each culture of Alexandrium catenella 6ax and TNY7 at the mid-exponential growth phase, adjusted to a concentration of $5.0 \times 10^{3}$ cells $\mathrm{ml}^{-1}$ with sterile $\mathrm{f} / 2-\mathrm{Si}$ medium, was then added to the 30 flasks, mixed gently, and incubated for $2 \mathrm{wk}$ or 1 mo under the conditions described before. During the incubation period, the growth of Alexandrium cells and total bacteria in triplicate flasks of each fraction were monitored once in $3 \mathrm{~d}$ by the method described before. After incubation for $0,4,7,14$ and $30 \mathrm{~d}$, external phosphate, nitrate/nitrite and ammonium concentrations in 3 separate flasks for each incubation were determined. After $2 \mathrm{wk}$ or $1 \mathrm{mo}$, the bottoms of the triplicate flasks were agitated with a rubber scraper. After scraping, $12 \mathrm{ml}$ aliquots of each culture were poured into 3 plastic disposable centrifugation tubes $(15 \mathrm{ml}$, Iwaki Co.), respectively, and then centrifuged at $1000 \times g$ for $10 \mathrm{~min}$. After $7 \mathrm{ml}$ of supernatant was removed, the residue was sonicated with Urtrasonic Disruptor (Model UR-200P, Tomy Seiko Co.) at the maximum output (output 11) for $1 \mathrm{~min}$ to destroy most vegetative cells and centrifuged again at $1000 \times g$ for $10 \mathrm{~min}$. After $4 \mathrm{ml}$ of supernatant was removed, cysts were resuspended and transferred into a well of a 48-well tissue culture plate. All the cysts in a well were counted under an inverted microscope as described before. Counts with and without sonication indicated that no cysts were destroyed by this process. Encystment efficiency was obtained as the cyst:peak cell concentration ratio (Anderson et al. 1984).

Bioassay for enumeration of Alex-GPB and Alex-GIB. The numbers of Alexandrium-growthpromoting bacteria (Alex-GPB) and -growthinhibiting bacteria (Alex-GIB) were determined by the MPN bioassay reported by Yoshinaga et al. (1995) in order to clarify the relationships between fluctuation of Alex-CFPB and fluctuations of Alex-GPB and Alex-GIB. A total of $1.5 \mathrm{ml}$ of BF $\left(10^{0}\right.$ to $\left.10^{-5}\right)$ or BFF from field seawater samples collected from March 24 to May 21, 1998, was poured into 5 sterile MPN tubes $(13 \mathrm{~mm})$ for each fraction. Three $\mathrm{ml}$ of Alexandrium catenella 6ax on the mid-exponential growth phase, adjusted to a concentration of $5.00 \times 10^{3}$ cells $\mathrm{ml}^{-1}$ with sterile $\mathrm{f} / 2$-Si medium, was then added to the 35 MPN tubes, mixed gently, and incubated for $2 \mathrm{wk}$ under the conditions described before. During the incubation period, the growth of Alexandrium cells in 5 replicates of each fraction were monitored every $5 \mathrm{~d}$ by in vivo autofluorescence excited by blue-light, using a Turner Fluorometer Model 10-AU (Turner Designs Inc.). After 2 wk incubation, the MPN tubes in which the algal growth was less than one-third and more than triple of that in the BFF control cultures were regarded as 'Alex-GIB-positive' and 'Alex-GPB-positive', respectively. MPN values of Alex-GIB and AlexGPB in the seawater samples were determined by a series of numbers for these 'positive' tubes by the method described by Yoshinaga et al. (1995). 


\section{RESULTS}

Alexandrium tamarense blooms and environmental conditions. Seasonal trends in water temperature at around $5 \mathrm{~m}$ depth at $\mathrm{Stn} 11$ each year were similar, with a continuous increase from $\mathrm{ca} 10^{\circ} \mathrm{C}$ in February to the annual maximum of 25 to $26^{\circ} \mathrm{C}$ in August and a steady decrease after September (Fig. 3C). Alexandrium tamarense were first observed at a seawater temperature of $10^{\circ} \mathrm{C}$ in February 1997 and 1998 and peaked around $15^{\circ} \mathrm{C}$ at the end of April (Fig. 3A). Maximum densities of 9.33 and $2.50 \times 10^{4}$ cells $l^{-1}$ occurred at the $5 \mathrm{~m}$ depth layer on April 21, 1997, and April 23, 1998, respectively. Blooms rapidly declined in the beginning of May in both years. Since $A$. tamarense was densely distributed at around $5 \mathrm{~m}$ depth during the peak period of blooms (data not shown), samples for estimating bacterial effects were collected from $5 \mathrm{~m}$ depth. Salinity ranged between a high of $>33$ in late winter and a low of 28 in July 1997 (Fig. 3C). Nutrient concentrations remained relatively high during the bloom initiation periods (February to beginning of March 1997 and 1998), decreased during the early bloom development periods (beginning of April 1997 and end of March 1998), and then became constant at a low level until the beginning of summer (Fig. 3D,E, F). The total number of bacteria fluctuated little $\left(1.06\right.$ to $2.86 \times 10^{6}$ cells $\mathrm{ml}^{-1}$, mean $2.16 \times 10^{6} \pm$ $\mathrm{SD}: 4.69 \times 10^{5}$ cells $\mathrm{ml}^{-1}$ ) over the observed period (Fig. 3B).

Bacterial effects on cyst yield. Fig. 4 shows the results of the small-scale bioassay (Fig. 2) using field seawater sampled on April 21, 1997, the period of Alexandrium tamarense bloom. After 1 mo of incubation, $822(\mathrm{SD}=187)$ cysts well ${ }^{-1}(\mathrm{n}=16)$ were formed in the $0.8 \mu \mathrm{m}$ filtrate seawater (bacteria fractions [BF]) wells, whereas fewer cysts (139 [SD $=91.0$ ] cysts well ${ }^{-1}, \mathrm{n}=18$ ) were obtained in the bacteria-free fractions (BFF: $0.2 \mu \mathrm{m}$ filtrates) wells (Fig. 4) and a significant difference in cyst yield was found ( $t$-test; $t=12.7$, $\mathrm{p}<0.001)$. Cyst formation declined with decreased bacterial inoculum (BF $10^{-1}$ to $10^{-5}$ ); the BF $10^{-5}$ concentration approximated that of the BFF medium (Fig. 4). The $F$-value of the 1 -way $\operatorname{ANOVA}\left(F_{6,117}\right)$ was $55.6(\mathrm{p}<0.001)$. Some cysts $(95.8$ [SD $=49.3$ ] cysts well ${ }^{-1}, n=18$ ) were formed in the wells with $f / 2-\mathrm{Si}$ media (Fig. 4). Most bacterial fractions of other seawater samples collected from 1997 to 1998 (data not shown) also promoted cyst formation of A. tamarense as shown in Fig. 4.
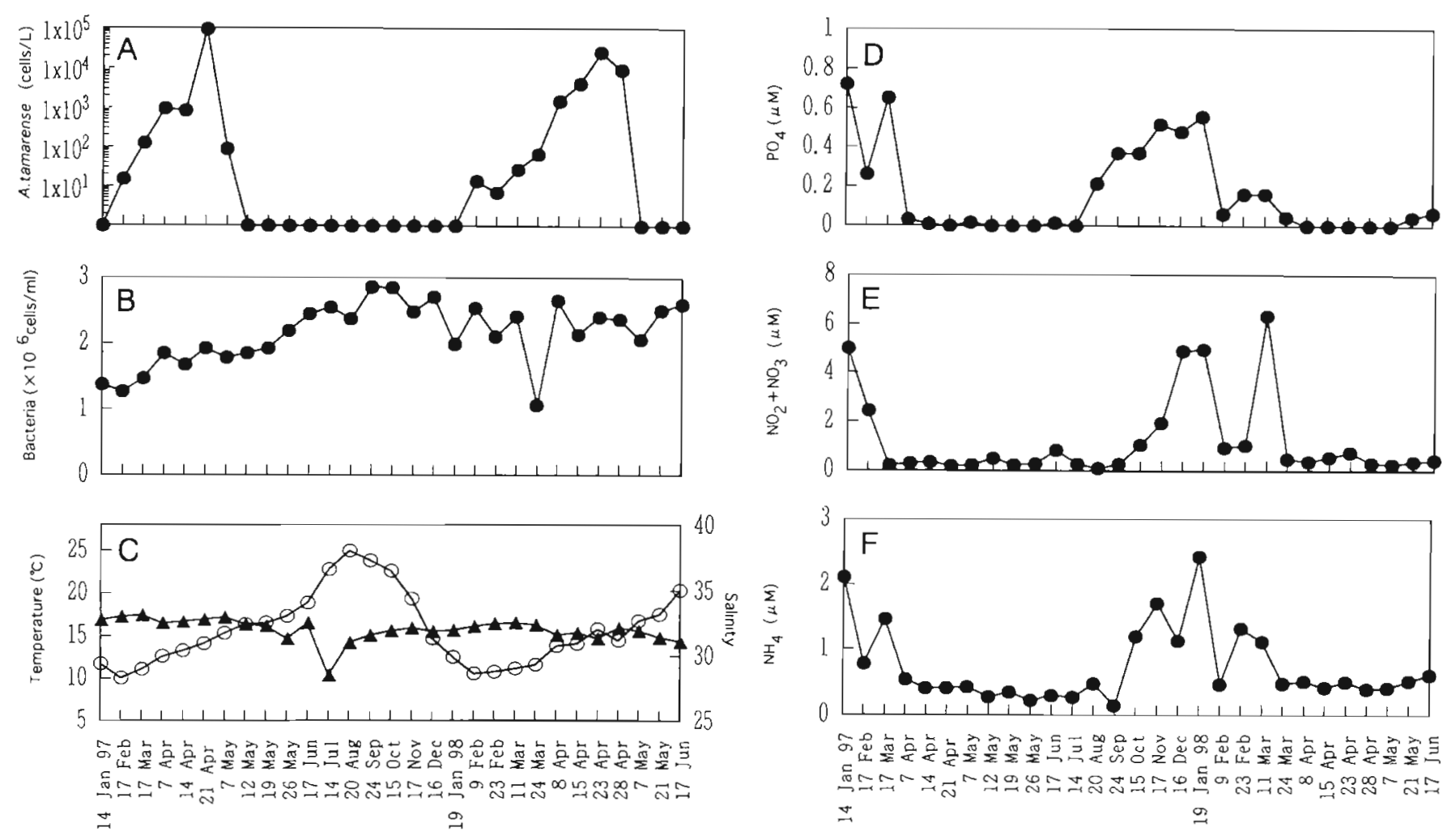

Fig. 3. Seasonal changes of (A) Alexandrium tamarense cell density, (B) total bacteria, (C) temperature (O) and salinity ( $\mathbf{A}$ ), (D) inorganic nutrient phosphate, (E) nitrate/nitrite, and (F) ammonium at $5 \mathrm{~m}$ depth at Str 11 from 1997 to 1998 


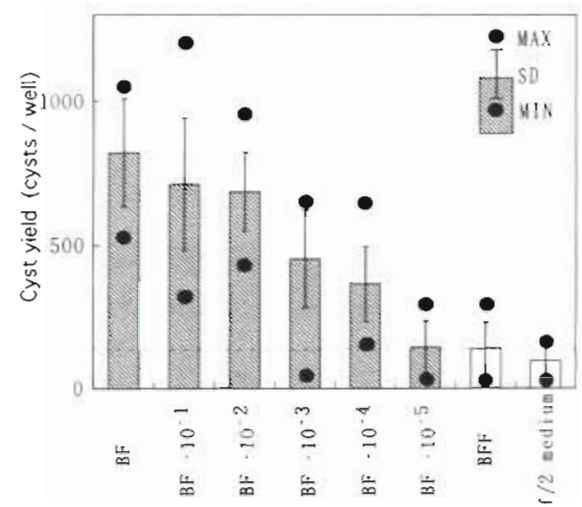

Fig. 4. Effects of bacterial assemblages in serially diluted seawater fractions collected from Hiroshima Bay on April 21, 1997, on cyst formation in Alexandrium catenella in BF $(n=16)$ and other fractions $(n=18)$ analyzed by the small-scale bioassay (see 'Materials and methods' $)$. $F$-value of the 1 -way ANOVA $\left(F_{6,117}\right)$ was 55.6 $(\mathrm{p}<0.001)$. (-) Maximum cyst number formed in each fraction (upper) and minimum cyst number in each fraction (lower)

Bacterial effects on encystment efficiency. When the large-scale bioassay was conducted using BF and BFF sampled during the period of bloom initiation (February 9) and during the bloom (April 28) in 1998, Alexandrium catenella cells grew almost similarly in flasks containing $B F$ or BFF samples of these periods and the peak algal cell density of the BF/ BFF was $2.90(\mathrm{SD}=0.345) \times$ $10^{4}$ cells $\mathrm{ml}^{-1} / 2.92(\mathrm{SD}=0.181) \times 10^{4}$ cells ml $\mathrm{ml}^{-1}$ (ratio: $99.3 \%$ on February 9$)$ and $3.28(\mathrm{SD}=0.105) \times$ $10^{4}$ cells ml-1/3.67 $(\mathrm{SD}=0.346) \times 10^{4}$ cells ml $\mathrm{ml}^{-1}$ (ratio: $89.3 \%$ on April 28), respectively (Fig. 5A,F, Table 1). In flasks with bacteria from February 9 and with bacteria from April 28, total bacteria increased from $5.40 \times 10^{5}$ to $5.62(\mathrm{SD}=0.340) \times 10^{7}$ cells $\mathrm{ml}^{-1}$ and from $7.92 \times 10^{5}$ to $6.80(\mathrm{SD}=0.568) \times$ $10^{7}$ cells $\mathrm{ml}^{-1}$ during the $1 \mathrm{mo}$ incubation, respectively (Fig. 5B,G). The number was almost 30 times the mean total number of bacteria in the field seawater $\left(2.16 \times 10^{6}\right.$ cells $\left.\mathrm{ml}^{-1}\right)$ (Fig. 3B). The phosphate concentration in flasks containing seawater of February 9 and of April 28, 1998 decreased similarly from 18.6 to $0.77 \mu \mathrm{M}(\mathrm{BF}) / 0.95 \mu \mathrm{M}(\mathrm{BFF})$ and from 18.1 to $0.68 \mu \mathrm{M}$ $(\mathrm{BF}) / 0.86 \mu \mathrm{M}(\mathrm{BFF})$, respectively (Fig. 5C,H). Their nitrate/nitrite concentration similarly decreased from $5.37 \times 10^{2} \mu \mathrm{M}$ to $3.94 \mu \mathrm{M}(\mathrm{BF}) / 4.87 \mu \mathrm{M}(\mathrm{BFF})$ and from $5.40 \times 10^{2} \mu \mathrm{M}$ to $6.44 \mu \mathrm{M}(\mathrm{BF}) / 6.93 \mu \mathrm{M}(\mathrm{BFF})$, respectively (Fig. 5D,I). The concentration of ammonium in the flasks added with BF sampled on February 9, 1998 was less than that in the BFF flasks throughout the incubation period (Fig. 5E). In the case of seawater of
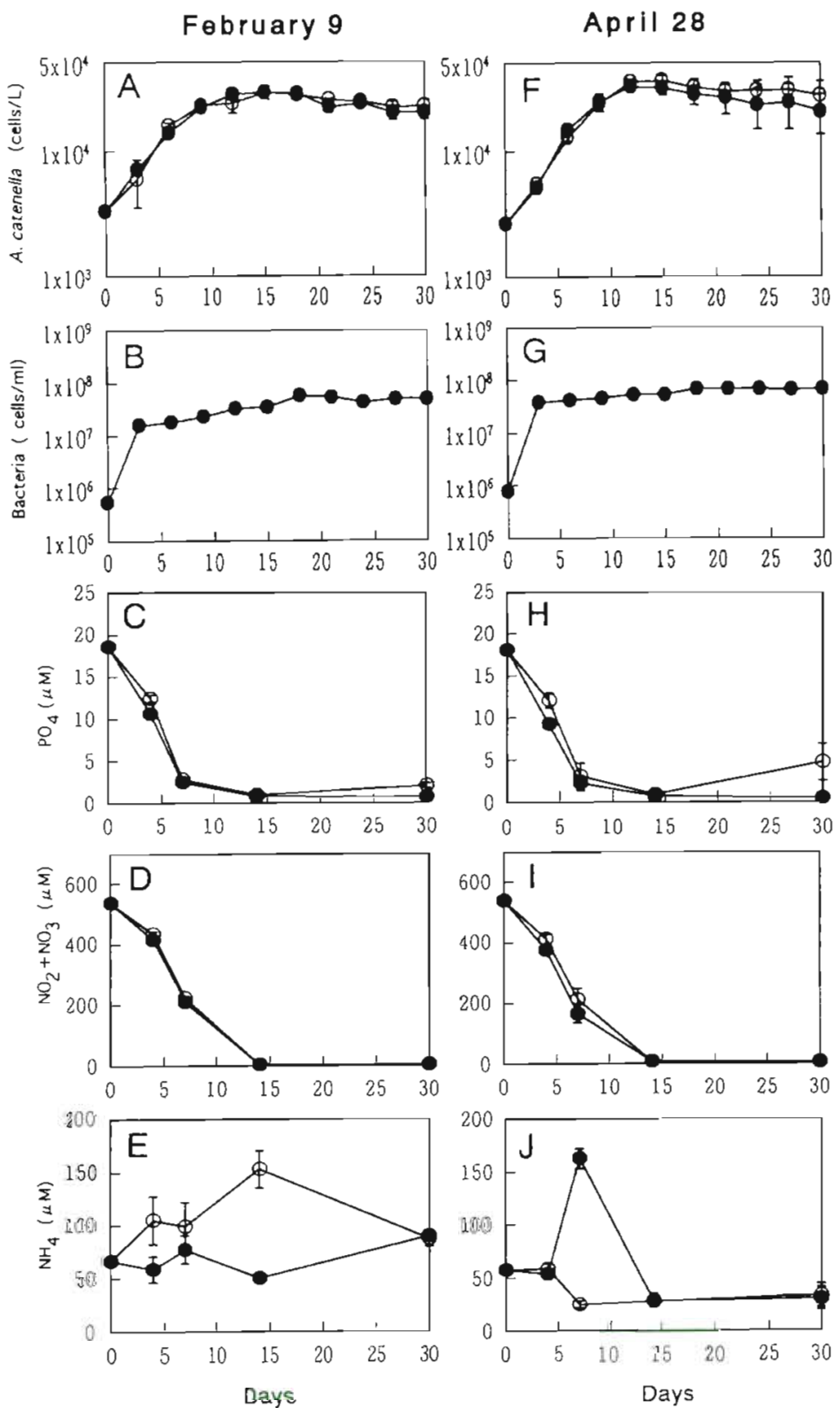

Fig. 5. Time-course measurements of (A,F) Alexandrium catenella density, $(B, G)$ total bacteria, and $(C, H)$ inorganic nutrient phosphate, $(D, l)$ nitrate/nitrite and $(E, J)$ ammonium in the large-scale bioassay cultures (see 'Material and methods') using BF and BFF of the field seawater of February 9 (bloom initiation period) (A to E) and of April 28 (bloom peak) (F to J), 1998. (O) BFF: (O) BF

April 28, ammonium concentration in BF was higher than that in BFF flasks after 1 wk of incubation (Fig. 5J). The cyst numbers counted after 2 wk and after 1 mo of incubation were almost the same (data not shown). The cyst yield in flasks containing BF and BFF from February 9, 1998, were $1.93(\mathrm{SD}=1.05)$ cysts $\mathrm{ml}^{-1}(\mathrm{BF})$ and $2.30\left(\mathrm{SD}=1.70 \times 10^{-1}\right)$ cysts $\mathrm{ml}^{-1}(\mathrm{BFF})$, 
Table 1. Peak number of cells, cyst yields and encystment efficiency in cultures of the large-scale bioassay using bacterial (BF) and bacteria-free fractions (BFF) of field seawater sampled on February 9 and April 28, 1998 (ns; not significant, $\cdots p<0.001$ )

\begin{tabular}{|c|c|c|c|c|}
\hline Seawater & Fraction & $\begin{array}{c}\text { Maximum cell yield } \pm \text { SD } \\
\left(\text { cells } \mathrm{ml}^{-1}\right)\end{array}$ & $\begin{array}{l}\text { Cyst yield } \pm \mathrm{SD} \\
\left(\text { cysts } \mathrm{ml}^{-1}\right)\end{array}$ & $\begin{array}{l}\text { Encystment efficiency } \\
\text { (cysts cell }{ }^{-1} \text { ) }\end{array}$ \\
\hline \multirow[t]{2}{*}{ February 9} & $\begin{array}{l}\mathrm{BF} \\
\mathrm{BFF}\end{array}$ & $\begin{array}{l}2.90 \pm 0.345 \times 10^{4} \mathrm{~ns} \\
2.92 \pm 0.181 \times 10^{4} \mathrm{~ns}\end{array}$ & $\begin{array}{l}1.93 \pm 1.05 \mathrm{~ns} \\
2.30 \pm 0.170 \mathrm{~ns}\end{array}$ & $\begin{array}{l}6.64 \times 10^{-5} \\
7.86 \times 10^{-5}\end{array}$ \\
\hline & $\mathrm{BF} / \mathrm{BFF}(\%)$ & 99.3 & 83.9 & 84.5 \\
\hline \multirow[t]{2}{*}{ April 28} & $\begin{array}{c}\mathrm{BF} \\
\mathrm{BFF}\end{array}$ & $\begin{array}{l}3.28 \pm 0.105 \times 10^{4} \mathrm{~ns} \\
3.67 \pm 0.346 \times 10^{4} \mathrm{~ns}\end{array}$ & $\begin{array}{l}15.7 \pm 0.538 \cdots \\
2.59 \pm 1.22 \cdots\end{array}$ & $\begin{array}{l}4.79 \times 10^{-4} \\
7.05 \times 10^{-5}\end{array}$ \\
\hline & $\mathrm{BF} / \mathrm{BFF}(\%)$ & 89.3 & 606 & 679 \\
\hline
\end{tabular}

respectively (Table 1). The encystment efficiency (the cyst yield: maximum cell ratio) in flasks containing BF and BFF from February 9, 1998, were $6.64 \times 10^{-5}$ cysts cell $^{-1}(\mathrm{BF})$ and $7.86 \times 10^{-5}$ cysts cell ${ }^{-1}(\mathrm{BFF})$, respectively (Table 1 ). The cyst yield in flasks containing $B F$ and BFF from April 28, 1998, were 15.7 (SD $=5.38 x$ $10^{-1}$ ) cysts $\mathrm{ml}^{-1}(\mathrm{BF})$ and $2.59(\mathrm{SD}=1.22)$ cysts $\mathrm{ml}^{-1}$ $(B F F)$, respectively (Table 1 ). The encystment efficiency in flasks containing BF and BFF from April 28, 1998, were $4.79 \times 10^{-4}$ cysts cell ${ }^{-1}(\mathrm{BF})$ and $7.05 \times 10^{-5}$ cysts cell ${ }^{-1}(\mathrm{BFF})$, respectively (Table 1$)$. These results show that in the seawater sampled in the bloom initiation period, the encystment efficiency under the BF conditions was almost the same as that under the BFF condition, whereas the encystment efficiency under the $\mathrm{BF}$ conditions was almost 7 times that under BFF conditions using seawater sampled during the blooming period (Table 1, Fig. 6B), although the nutrient level was not different between the 2 series of the large-scale experiments (Fig. 5). The ratio of encystment efficiency under the BF conditions and that under the BFF conditions increased during the bloom initiation period (Fig. 6B).

Relationships between abundance of Alexandrium tamarense and fluctuation of CFPB. The number of Alexandrium-cyst-formation-promoting bacteria (AlexCFPB) in the seawater samples determined by the small-scale MPN bioassay increased from the beginning of the A.tamarense bloom on February 17, 1997. and reached $3.60 \times 10^{3}$ cells $\mathrm{ml}^{-1}$ at the peak bloom period on April 21, 1997 (Fig. 6A). As the bloom declined at the beginning of May, Alex-CFPB decreased rapidly and dropped to less than 1 cell $\mathrm{ml}^{-1}$ on May 12, 1997 (Fig. 6A). After the bloom in 1997, the next peak of Alex-CFPB was observed on June 17, 1997, when dinoflagellate cells were not detected, and then AlexCFPB fluctuated from $1.56 \times 10^{0}$ to $1.58 \times 10^{3}$ cells $\mathrm{ml}^{-1}$. Alex-CFPB dropped to less than 1 cell $\mathrm{ml}^{-1}$ by the initiation of the bloom on February 23,1998, then increased and reached $1.00 \times 10^{3}$ cells $\mathrm{ml}^{-1}$ by the end of April 1998 when the peak of $A$. tamarense was observed. As the bloom decayed, the number of Alex-CFPB de-

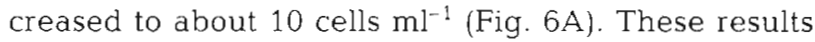
show a clear positive correlation between number of cells of Alex-CFPB and the abundance of A.tamarense during the blooms in 1997 and $1998(Y=24.6 \mathrm{X}-2.65 \times$ $\left.10^{3}, \mathrm{r}^{2}=0.861, t=7.863, \mathrm{p}<0.001\right), X$ : Alex-CFPB, $Y$ : Alexandrium). Alexandrium-cyst-formation-inhibiting bacteria (Alex-CFIB) were not detected by the MPN method during the observation period. These results also showed a clear positive correlation between the number of cells of Alex-CFPB (Fig. 6A) and the ratio of encystment efficiency under BF/BFF during the bloom in 1998 (Fig. 6B).

Relationships between abundance of Alexandrium tamarense and fluctuation of Alex-GPB and Alex-GIB. The number of Alexandrium-growth-promoting bacteria (Alex-GPB) determined by the MPN bioassay increased from the beginning of the Alexandnum tamarense bloom on March 24, 1998, and reached $4.67 \times 10^{2}$ cells $\mathrm{ml}^{-1}$ on April 15, 1998, just before the peak bloom period. After that, Alex-GPB decreased rapidly and dropped to less than 1 cell $\mathrm{ml}^{-1}$ in the period of bloom disintegration (Fig, 6C). The number of Alexandrium-growth-inhibiting bacteria (Alex-GIB) increased from April 8, 1998, reached $5.53 \times 10^{1}$ cells $\mathrm{ml}^{-1}$ at the peak bloom period on April 23, 1998, and then dropped to about $1.00 \times 10^{1}$ cells $\mathrm{ml}^{-1}$ (Fig. 6C).

Forms of cysts and their germination. Forms of cysts obtained from BF and BFF were normal and similar to those found in the field bottom sediment. All of the cysts formed in BF had the developed clear-zones around the cells, whereas cysts formed in BFF had undeveloped and faint clear-zones. The probability of excystment ranged from 85.2 to $97.8 \%$ (mean $=92.8 \%$, $\mathrm{SD}=6.71$ ) when they were incubated at $20^{\circ} \mathrm{C}$ with a 14:10 h light:dark cycle after storage at $5^{\circ} \mathrm{C}$ in the dark for $1 \mathrm{mo}$ 

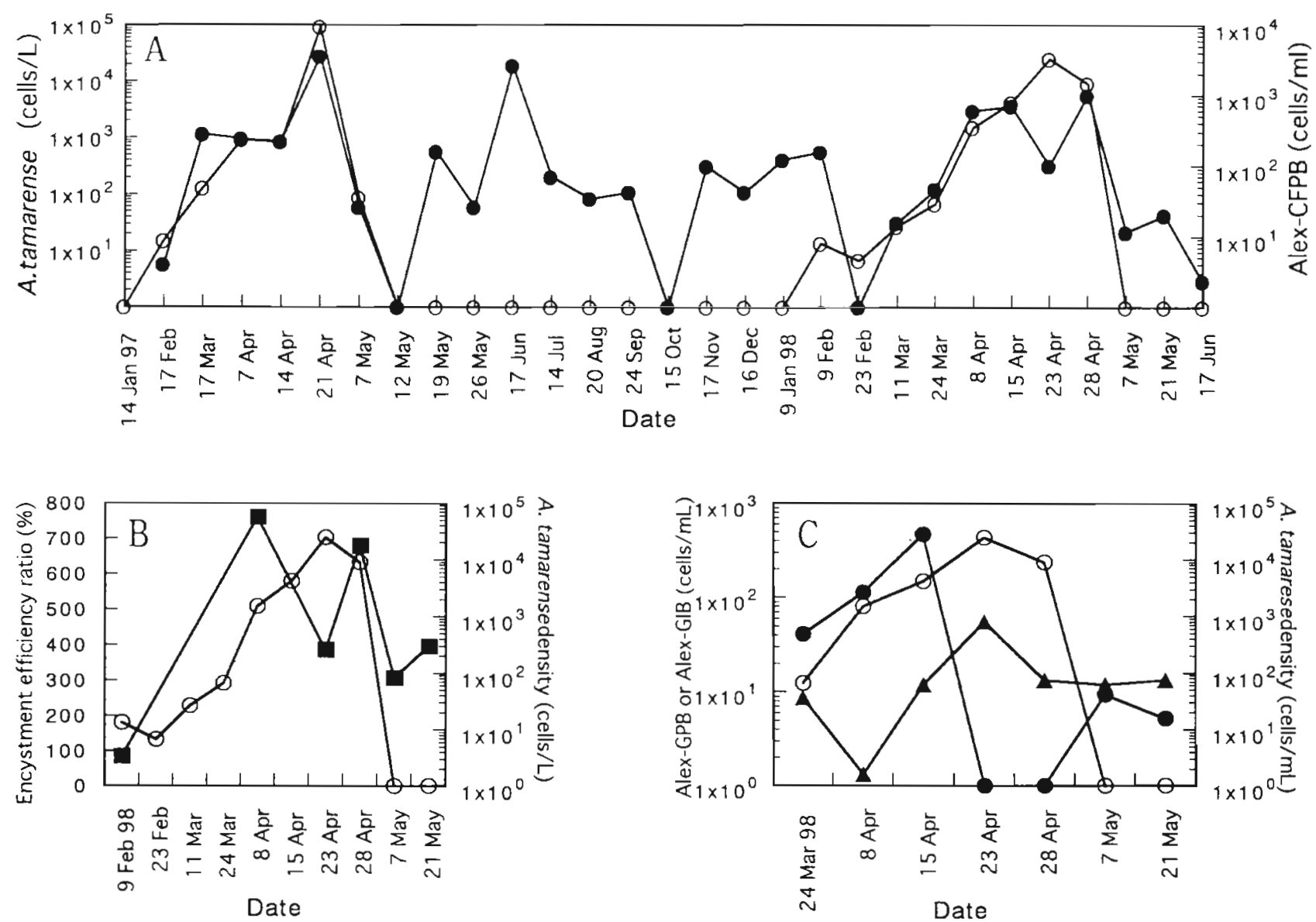

Fig. 6. Relationships between fluctuations of (A) the number of Alex-CFPB (-) determined by the small-scale bioassay, (B) the

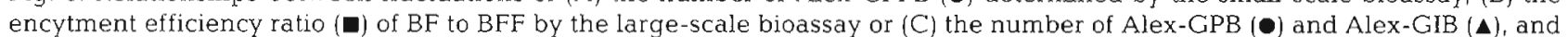
Alexandrium tamarense density $(0)$ at Stn 11 in Hiroshima Bay

\section{DISCUSSION}

Promotion of encystment by natural bacterial assemblages. We focused on one of the possible biological factors, bacteria, as the factor that triggers/ promotes encystment of the toxic dinoflagellate Alexandrium and conducted small- and large-scale bioassays using $\mathrm{BF}$ or $\mathrm{BFF}$ of natural seawater from Hiroshima Bay in 1997 to 1998 to examme the roles of natural bacterial assemblages on cyst formation of toxic Alexandrium in the field. Results suggest that the natural bacterial assemblages enhanced encystment of Alexandrium. The abundance or activity of Alex-CFPB increased as the bloom developed and reached the maximum concentration at the peak period of the bloom. After that, Alex-CFPB decreased rapidly as the bloom declined. The clear positive correlation between the abundance of $A$. tamarense and Alex-CFPB during the bloom periods suggests that the Alex-CFPB play a significant role in the process of encystment and bloom disintegration in the field. The existence of Alex-CFPB during the non-blooming period suggests that AlexCFPB exist throughout the year.

The MPN counting of Alex-CFPB. In each MPN microwell containing BF, not only Alex-CFPB but also Alex-CFIB, although the latter were not detected in this study, probably exist, so that a succession of these bacterial populations may occur in each well. Therefore, the MPN of Alex-CFPB in this study might be underestimated, since the stimulative effects on encystment may reflect the balance of effects of AlexCFPB and Alex-CFIB. The number of Alex-CFPB and Alex-CFIB may also be affected by the coexisting Alex-GPB and Alex-GIB in the MPN wells, since the growth in the wells was not monitored in our smallscale bioassay. Results of the fluctuation of Alex-GPB and Alex-GIB in Hiroshima Bay showed that the AlexGPB disappeared and many Alex-GIB were detected at around the peak bloom period of Alexandrium tamarense as well as Alex-CFPB during the blooming in 1998, which suggests that the number of Alex-CFPB at that time have perhaps been underestimated. Fur- 
thermore, our estimates of bacteria may be underestimated by the filtration of field seawater with $\mathrm{GF} / \mathrm{F}$ as well as $0.8 \mu \mathrm{m}$ filter in some cases.

Promotion of encystment not by nutrient depletion but by bacteria. In the large-scale bioassay, cyst numbers counted after 2 wk and after 1 mo incubation were almost the same, indicating that cyst formation mainly occurred within the first $2 \mathrm{wk}$. Considering that it takes about 1 wk to mature from fused cells (planozygotes) to resting cysts (hypnozygotes) (Anderson et al. 1983), fusion probably mainly occurred within the first week. During this fusion period, macronutrient (phosphate/ nitrite/nitrate) concentrations in flasks containing BF and BFF sampled on February 9, 1998 decreased at almost the same rate as the nutrient concentration in flasks containing BF and BFF sampled on April 28, 1998, whereas the difference between the encystment efficiency in these samples at bloom initiation and bloom periods was detected. These results suggest that the difference was caused not by the effects from macronutrient limitation but by the effects of bacteria sampled at the bloom period.

Promotion effects of encystment by bacteria. Encystment efficiency under BF conditions using seawater containing 'bloom peak' bacteria in the large-scale bioassay was much higher than that under BF conditions using seawater containing 'bloom initiation' bacteria, though total bacteria grew almost similarly in flasks containing these 2 types of seawater. These results suggest that the florae of bacteria which were contained in these 2 types of seawater were quite different and the encystment promotion was not caused by 'general' bacteria but by some bacteria that increased at the bloom period.

Timing of encystment in the field. Anderson et al. (1983) reported that, in their study of dynamics of Alexandrium tamarense in Perch Pond, USA, planozygotes had already emerged during the bloom development period and reached a maximum at around the peak of the bloom and then decreased as the bloom declined. Although planozygotes were not counted in our work, our observations that Alex-CFPB increased during the bloom development, reached the maximum at the around bloom peak, and then decreased during the bloom disintegration period correspond to their observations on planozygote dynamics.

Trigger of encystment. In the laboratory cultures, some cysts were formed in wells containing BFF and nutrient-replete f/2-Si media, which suggests that neither the bacterial assemblages nor nutrient-depletion were the trigger for cyst formation in our experiments. The trigger of encystment remains obscure in our experiments. The possibility of an endogenous or 'clock' regulated sexuality might be considered (Anderson et al. 1995).
In the field, it is not clear that natural bacteria triggered the encystment, whereas they promoted the cyst formation. Yet this does not necessarily exclude the possibility that bacteria act as the trigger of encystment in the field. Considering the field environmental parameters, after nutrient concentration decreased rapidly at the beginning of April 1997 and at the end of March 1998, cells of Alexandrium tamarense were supposed to divide several times until the peak bloom period and to contain cellular nitrogen or phosphorus at critical or threshold levels before or at the peak bloom period. The putative nutrient depletion might have triggered the encystment during the blooms in 1997 and 1998.

Encystment efficiency. We estimated the effects of bacteria on the encystment efficiency calculated from the division of cyst yields by maximum cell yields according to the method described by Anderson et al. (1984). Considering that the cyst number counted $2 \mathrm{wk}$ and 1 mo after the crossing was almost the same and that the maximum density was always obtained around 2 wk after the crossing, the efficiency may be reliable. More accurate estimates require continuous monitoring of cyst abundance as well as planozygote cells throughout each experiment, so that cells that successfully fuse to form planozygotes or cysts can be included in the motile cell totals (Watanabe et al. 1982).

Difference of cyst yield in small- and large-scale bioassays. Cyst yield produced in each well $(1.5 \mathrm{ml})$ of disposable sterilized polystyrene tissue culture microplates used for small-scale bioassay was always higher than that obtained in each grass flask $(100 \mathrm{ml})$ used for large-scale bioassay. However, the clear positive correlation between abundance of Alex-CFPB obtained using small-scale bioassay and the activity of Alex-CFPB obtained using large-scale bioassay suggests that the difference of cyst yields was not caused by an error in experiment but by the difference of material, size or shape between wells of microplates and flasks.

Nature of cysts formed in our experiments. Anderson et al. (1984) reported that some of the cysts produced under phosphate depletion were not of the typical shape. Forms of cysts obtained in this study were normal under $\mathrm{BF}$ and $\mathrm{BFF}$ treatments and similar to those found in field bottom sediments. All of the cysts formed in BF had developed clear-zones around the cells, whereas cysts formed in BFF had undeveloped and faint clear-zones. This suggests that the clearzones may be induced by the existence of natural bacteria assemblages. The high excystment rate also suggests that the cysts formed in our experiments were normal.

Promotion and inhibition of phytoplankton growth by natural bacterial assemblages. Fukami et al. (1991) clarified that the activity of Gymnodinium mikimotoi- 
growth-promoting-bacteria (Gm-G.PB) by their bioassay increased as the bloom developed and reached maximum at the peak period of the bloom in Uranouchi Inlet, Japan. Yoshinaga et al. (1995) reported that the number of Gymnodinium mikimotoi-growthinhibiting bacteria (Gm-GIB) determined by the MPN method increased during the peak bloom period in Tanabe Bay, Japan. Our results of fluctuation of Alex-GPB and Alex-GIB almost corresponded with their results of Gm-GPB and Gm-GIB, which suggests that natural bacterial assemblages may play an important role in the development and decay of algal blooms.

Natural bacteria affect bloom dynamics of marine phytoplankton. This is the first report on the ecological role of natural bacterial assemblages on sexual reproduction of marine phytoplankton species. Recently, some bacteria that affect sexuality or growth of various marine phytoplankton have been isolated from natural marine environments. A bacterium that promotes sperm formation of the diatom Coscinodiscus wailesii Gran was isolated from sediment from Harima-Nada (Japan) (Nagai et al. 1994). Sawayama et al. (1993) reported that a bacterium inhibited the mating reaction of Alexandrium catenella. These bacteria might affect sexual reproduction of natural phytoplankton species in the field, although these papers did not analyze their abundance or ecological roles in the field. Furthermore, some researchers have clarified that bacterial assemblages in natural seawater affect the growth of specific marine phytoplanktons as well as their succession in the field (Riquelme et al. 1987. Fukami et al. 1991, Yoshinaga et al. 1995). These findings suggest that natural bacterial assemblages play an important role in bloom dynamics of phytoplankton in marine ecosystems

Acknowledgements. This work was supported by Grant-inAid for Encouragement of Young Scientists (Nos. 08760181 and 09760179j from the Ministry of Education, Science, Sports and Culture of Japan. We thank Drs R. Kondo and Y Sako for providing cultures of Alexandrium. We also thank Mr K Irifuku for his technical assistance, and Dr K. Fukami for valuable advice.

\section{LITERATURE CITED}

Adachi M, Sako Y, Ishida Y (1996) Analysis of Alexandrium (Dinophyceae) species using sequences of the 5.8S ribosomal DNA and internal transcribed spacer regions. J Phycol $32: 424-432$

Anderson DM, Lindquist NL (1985) Time-course measurements of phosphorus depletion and cyst formation in the dinoflagellate Gonyaulax tamarensis Lebour. J Exp Mar Biol Ecol 86:1-13

Anderson DM. Morel FMM (1979) The seeding of two red tide blooms by the germination of benthic Gonyaulax tamarensis hypnocyst. Estuar Coast Mar Sci 8:279-293 Anderson DM. Wall D (1978) The potential importance of benthic cysts of Gonyaulax tamarensis and Gonyaulax excavata in initiating toxic dinoflagellate blooms. J Phycol $14: 224-234$

Anderson DM, Chisholm SW, Watras CJ (1983) Importance of life cycle events in the population dynamics of Gonyaulax tamarensis. Mar Biol 76:179-189

Anderson DM, Kulis DM, Binder BJ (1984) Sexuality and cyst formation in the dinoflagellate Gonyaulax tamarensis: cyst yield in batch cultures. J Phycol 20:418-425

Anderson DM, Fukuyo Y, Matsuoka K (1995) Cyst methodologies. In: Hallegraeff GM, Anderson DM, Cembella AD (eds) IOC manuals and guides: manual on harmful marine microalgae. UNESCO, Paris, p 229-249

Dale B (1977) Cysts of the toxic red-tide dinoflagellate Gonyaulax excavata (Braarud) Balech from Oslotjorden, Norway. Sarsia 63:29-34

Doucette GJ, Cembella AD, Boyer GL (1989) Cyst formation in the red tide dinoflagellate Alexandrium tamarense (Dinophyceae): effects of iron stress. J Phycol 25:721-731

Fukami K, Nishijima T, Murata H, Doi S, Hata Y (1991) Distribution of bacteria influential on the development and the decay of Gymnodinium nagasakiense red tide and their effects on algal growth. Nippon Suisan Gakkaishi 57: $2321-2326$

Guillard RR, Ryther JH (1962) Studies of marine planktonic diatoms. 1. Cyclotella nana Hustedt and Detonula confervacea (Cleve). Gran. Can J Microbiol 8:229-239

Hallegraeff GM (1993) A review of harmful algal blooms and their apparent global increase. Phycologia 32:79-99

Imai I, Yamaguchi M (1994) A simple technique for establishing axenic cultures of phytoflagellates. Bull Jpn Soc Microb Ecol 9:15-17

Imai I, Kim MC, Nagasaki K, Itakura S, Ishida Y (1998) Detection and enumeration of microorganisms that are lethal to harmful phytoplankton in coastal waters. Plankton Biol Ecol 45:19-29

Nagai S, Hori Y, Manabe T, Imai I (1994) Promotion of sperm formation of a giant diatom Coscinodiscus wailesii Gran by a marine bacterium. Fish Sci 60:625-626

Perez CC, Roy S, Levasseur M. Anderson DM (1998) Control of germination of Alexandrium tamarense (Dinophyceae) cysts from the Lower St. Lawrence Estuary (Canada). J Phycol 34:242-249

Pfiester L, Anderson DM (1987) Dinoflagellate reproduction. In: Taylor FJR (ed) Biology of dinoflagellates. Blackwell Scientific Publications, Oxford, p 611-648

Porter KG, Feig YS (1980) The use of DAPI for identifying and counting aquatic microflora. Limnol Oceanogr 25:943-948

Riquelme CE, Fukami K, Ishida Y (1987) Annual fluctuations of phytoplankton and bacterial communities in Maizuru Bay and their interrelationship. Bull Jpn Soc Mirob Ecol 2:29-37

Sako Y, Kim CH, Ninomiya H, Adachi M, Ishida Y (1990) Isozyme and cross analysis of mating populations in the Alexandrium catenella/tamarense species complex. In: Granéli E, Sundström B, Edler L, Anderson DM (eds) Toxic marine phytoplankton. Elsevier, New York, p 320-323

Sako Y, Kim CH, Ishida Y (1992) Mendelian inheritance of paralytic shellfish poisoning toxin in the marine dinoflagellate Alexandrium catenella. Biosci Biotech Biochem 56: 692-694

Sawayama S, Sako Y, Ishida Y (1993) New inhibitor for mating reaction of Alexandrium catenella produced by marne Alteromonas sp. Nippon Suisan Gakkaishi 59: $291-294$ 
Shumway SE (1993) A review of the effects of algal blooms on shellfish and aquaculture. J World Aquacult Soc 21. $65-104$

Sokal RR, Rohlf FJ (1995) Biometry, 3rd edn. WH Freeman \& Co, New York

Steidinger KA (1975) Basic factors influencing red tides. In: LoCicero VR (ed) Toxic dinoflagellate blooms. Elsevier. Wakefield, MA, p 153-162

Turpin DH, Dobell PER, Taylor FJR (1978) Sexuality and cyst formation in Pacific strains of the toxic dinoflagellate Gonyaulax tamarense. J Phycol 14:235-238

Editorial responsibility: Otto Kinne (Editor),

Oldendorf/Luhe, Germany
Watanabe MM, Watanabe M, Fukuyo Y (1982) Encystment and excystment of red tide flagellates. I. Induction of encystment of Scrippsiella trochoidea. Res Rep Natl Inst Environ Stud 30:27-43

Yoshimatsu S (1981) Sexual reproduction of Protogonyaulax catenella in culture. Bull Plankton Soc Jpn 28:131-139

Yoshinaga I, Kawai T, Takeuchi T, Ishida Y (1995) Distribution and fluctuation of bacteria inhibiting the growth of a marine red tide phytoplankton Gymnodinium mikimotoi in Tanabe Bay (Wakayama Pref., Japan). Fish Sci 61. $780-786$

Submitted: April 30, 1999; Accepted: July 30, 1999 Proofs received from author(s): December 22, 1999 